УДК: 551.242:004.4; https://doi.org/10.37878/2708-0080/2021-4.01

\title{
КОЛЬЦЕВАЯ СТРУКТУРА В НАДСОЛЕВЫХ ОТЛОЖЕНИЯХ ПРИКАСПИЙСКОЙ ВПАДИНЫ
}

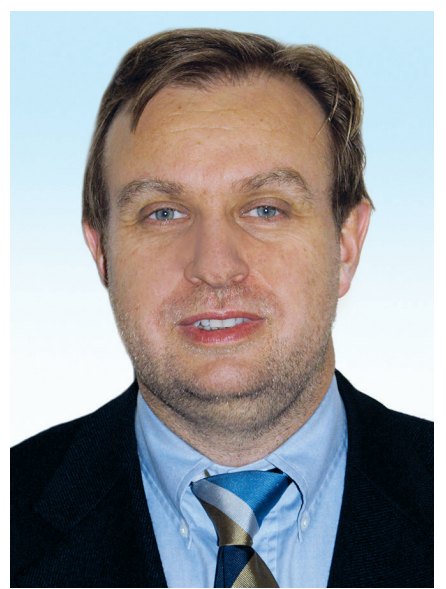

А.А. ГОЛЬМШТОК', директор, https://orcid.org/0000-00016638-3153

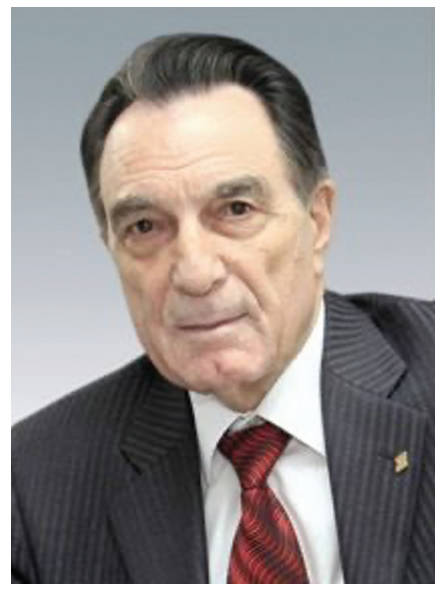

Н.К. НАДИРОВ ${ }^{2}$, первый вице-президент Национальной инженерной академии РК, академик АН Казахской ССР, Почетный нефртяник СССР, https://orcid.org/0000-00026315-9954

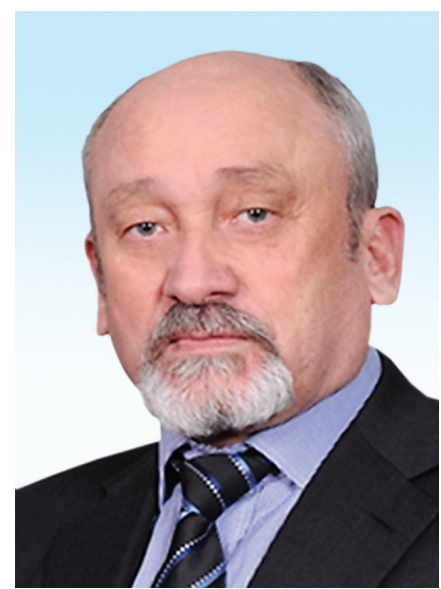

Н.Г. МАТЛОШИНСКИЙ ${ }^{1 *}$, технический директор, кандидат геол.-мин. наук, https://orcid.org/0000-00018028-782X

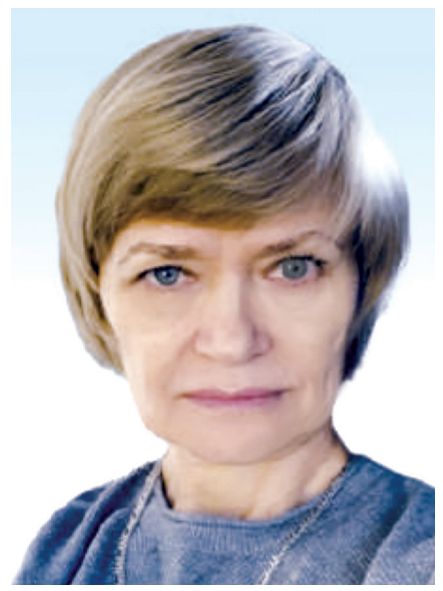

Н.А. СУЯРКОВА ${ }^{1}$, главный геофизик, https://orcid.org/0000-00033306-6930

* Адрес для переписки. E-mail: nmatloshinskiy@gmail.com 
${ }^{1}$ TOO «RESERVOIR EVALUATION SERVICES»

Республика Казахстан, 050044, г. Алматы, ул. Ахмедиярова, 24

²НАЦИОНАЛЬНАЯ ИНЖЕНЕРНАЯ АКАДЕМИЯ РЕСПУБЛИКИ КАЗАХСТАН, Республика Казахстан, 050010, г. Алматы, ул. Богенбай батыра 80

В меловых отложениях надсолевого комплекса Прикаспийской впадины в сейсмических данных выявлена кольцевая структура, которая представляет несомненный интерес в плане понимания строения комплекса в целом. Анализ показывает, что данная структура не очень соответствует формированию ударного метеоритного кратера. Она больше подходит под объект, образованный солянокупольной тектоникой, хотя сам по себе достаточно необычный. Дальнейшее изучение структуры может пролить свет на особенности строения надсолевого комплекса для лучшего понимания триады его нефтегазоносности: 1) очаги генерации; 2) пути миграции; 3) области аккумуляции.

КЛЮЧЕВЫЕ СЛОВА: кольцевая структура, сейсморазведка ЗД, надсолевой комплекс, нижнемеловые отложения, ударный метеоритный кратер, солянокупольная тектоника, галокинез.

\title{
КАСПИЙ МАҢЫ ОЙПАТЫНЫҢ ТҰЗҮСТІ ШӨГІНДІЛЕРІНДЕГІ АЙНАЛМА ҚҰРЫЛЫМ
}

\author{
А.А. ГОЛЬМШТОК' \\ Н.Г. МАТЛОШИНСКИЙ', техникалық директор, https://orcid.org/0000-0001-8028-782X \\ Н.К. НӘДІРОВ 2 , Қазақстан Республикасы Ұлттык инженерлік академиясынын академигі, https:// \\ orcid.org/0000-0002-6315-9954

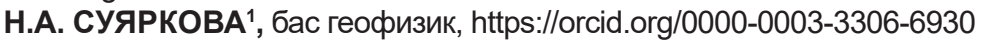 \\ ${ }^{1}$ ЖШC «RESERVOIR EVALUATION SERVICES», \\ Қазақстан Республикасы, 050044, Алматы қ. Ахмедияров к-сі 24 \\ ²ҚАЗАҚСТАН РЕСПУБЛИКАСЫ ҰЛТТЫК ИНЖЕНЕРЛІК АКАДЕМИЯ, \\ Қазакстан Республикасы, 050010, Алматы қ., Бөгенбай батыр көш., 80
}

Каспий маңы ойпатының тұздан кейінгі кешенінің бор шөгінділерінде сейсмикалық мәліметтер сақиналық құрылымды анықтады, бұл кешеннің құрылымын тұтастай түсіну тұрғысынан қызығушылық тудырады. Талдау көрсеткендей, бұл құрылым метеориттік кратердің пайда болуына онша сәйкес келмейді. Ол тұзды-күмбезді тектоникадан пайда болған объект үшін қолайлы, дегенмен бұл өзі ерекше. Құрылымды әрі қарай зерттеу, оның мұнай-газ әлеуетінің үштігін жақсы түсіну үшін тұздан кейінаі кешеннің құрылымдық ерекшеліктеріне жарық түсіруі мүмкін: 1) генерация орталықтары; 2) көші-қон жолдары; 3) жинақтау аймақтары.

TYЙІн СӨзДЕР: сақиналық құрылым, 3D сейсмикалық, тұз кешені, төменгі бор шөгінділері, соққы метеорит кратері, тұзды күмбез тектоникасы, жойылу.

\section{RING STRUCTURE IN OVERSALINE DEPOSITS OF THE PRECASPIAN DEPRESSION}

A.A. GOLMSTOCK ${ }^{1}$, Director

N.G. MATLOSHINSKIY1', Technical Director, https://orcid.org/0000-0001-8028-782X

N.K. NADIROV2, academician of National Engineering Academy, https://orcid.org/0000-0002-6315-9954

N.A. SUYARKOVA', Chief Geophysicist, https://orcid.org/0000-0003-3306-6930

${ }^{1}$ «RESERVOIR EVALUATION SERVICES» LLP

24, Akhmediyarov st., Almaty, Republic of Kazakhstan, 050044

${ }^{2}$ NATIONAL ENGINEERING ACADEMY OF KAZAKHSTAN

80, Bogenbai batyr str., Almaty, Republic of Kazakhstan, 050010 
In chalk deposits of the oversaline complex of the PreCaspian Depression, according to seismic data, a ring structure was revealed, which is of undoubted interest from the point of view of understanding the structure of the complex. Analysis shows that this structure does not really correspond to the formation of an impact meteorite crater. It is more suitable for an object formed by salino-dome tectonics, although rather unusual. Further study of the structure can reveal the structural features of the oversaline complex for a better understanding of the triad of its oil and gas potential: 1) generation centers; 2) migration routes; 3) accumulation areas.

KEY WORDS: ring structure, 3D seismic, oversaline complex, Lower Cretaceous deposits, impact meteorite crater, salino-dome tectonics, halokinesis.

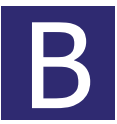

ходе проведения работ по переобработке и переинтерпретации сейсморазведочных данных в ТОО «Reservoir Evaluation Services» была выявлена кольцевая структура в надсолевом разрезе Прикаспийской впадины. Необычный характер структуры сразу же привлек к ней внимание, однако попытки объяснить ее природу оказались не такими и легкими. В связи с этим было решено обратиться к академику Надирову Н.К. как очень ответственному ученому, организатору и популяризатору изучения различного рода явлений, в том числе связанных с миграцией УВ в недрах планеты [1-4]. После совместного анализа материалов было принято решение опубликовать эти данные для широкого обсуждения, изложив на них полученную точку зрения.

Кольцевая структура (в дальнейшем «объект») представлена на рисунках 1-3. Характер структуры, представляющей собой практически идеально круглое образование диаметром порядка 4,7-4,8 км с наличием центрального поднятия, мог бы указывать на то, что в данном случае мы имеем дело с метеоритным кратером мелового возраста. Ширина кольца достигает 1,0 км, а ширина центрального поднятия превышает его в два раза (1,6-2,0 км) при общей площади объекта около 20 км². Однако примерно четвертая часть структуры на ее юго-востоке сейсморазведкой ЗД не перекрыта и кольцевой ее характер на этой части можно только предполагать.

В случае если структура обусловлена падением метеорита, это событие могло бы произойти на границе раннего и позднего мела. На сейсмическом разрезе (рисунок 2) прогнутая часть объекта, которая могла бы соответствовать кратеру с комплексом его заполнения, залегает на горизонте II, к этой возрастной границе приуроченным. Характерно, что объект сверху и снизу ограничивается горизонтальными, выдержанными на большей части наблюдаемой его площади, отражениями, указывая на то, что само событие, к которому привело его появление приурочено к определенному времени.

Отвечает ли строение кольцевой структуры формированию ее как ударного кратера метеорита? Наиболее известным из таких кратеров является Аризонский (рисунок 4). Аризонский кратер, как считается, возник в результате падения на Землю «тяжелого» метеорита размером около 30-70 м и массой в 70-300 тыс. т (по некоторым данным до 2 млн.т) около 50 тысяч лет назад. Вокруг кратера и в нем собрали более 30 т обломков метеоритного железа, самый крупный из которых весил 639 кг. Здесь же были найдены первые алмазы метеоритного (ударного) происхождения. Современные размеры кратера: диаметр - 1220 м, глубина - 184 м, возвышение вала -50 м.

Мощность взрыва при формировании кратера оценивается в 150 мегатонн тротилового эквивалента или в тысячу раз мощнее хиросимской бомбы, что также 


\section{ГЕОЛОГИЯ}

Ю3

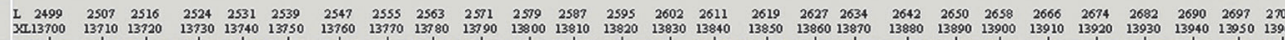

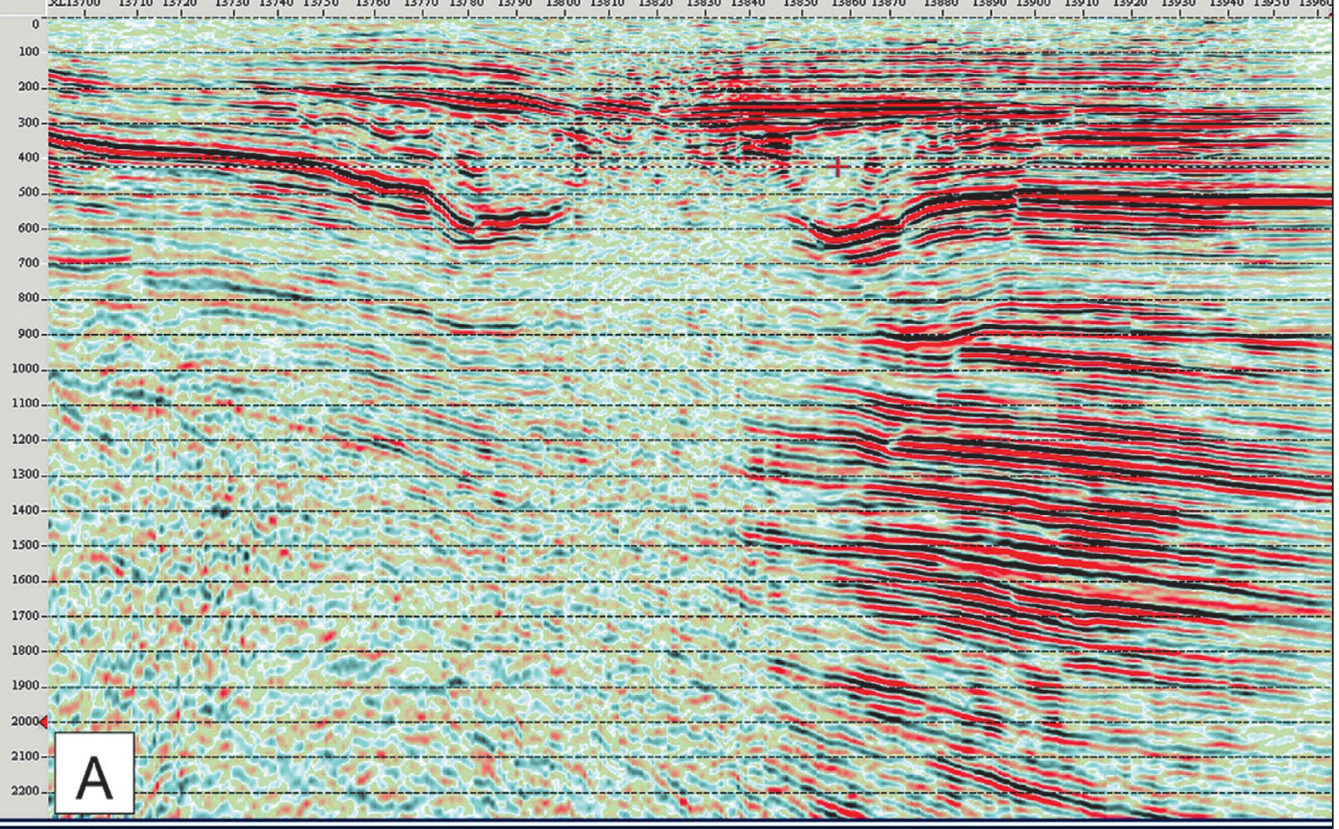

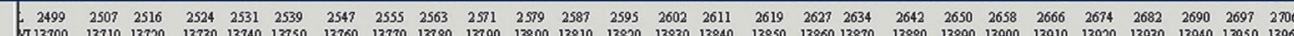

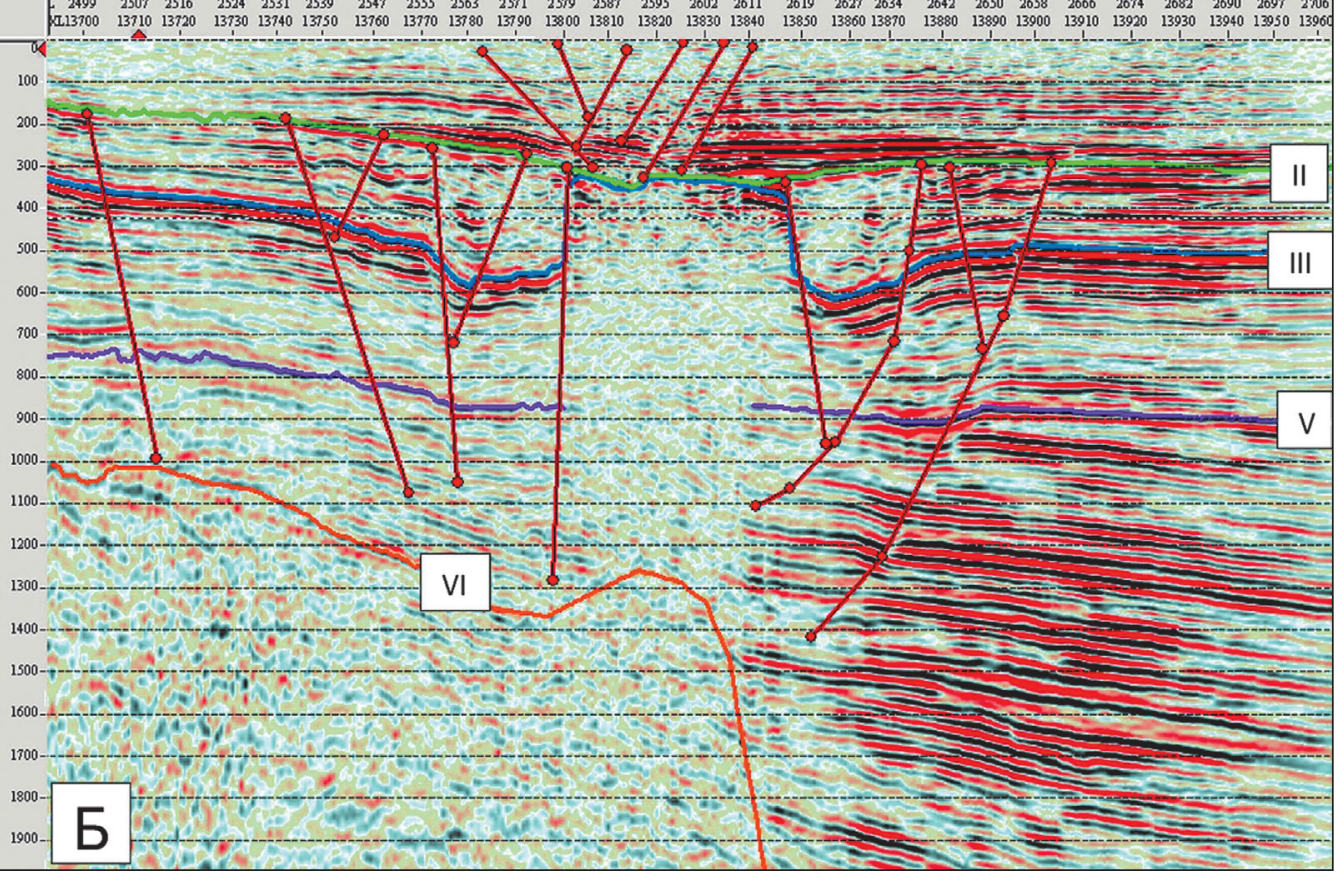

Рисунок 1 - Композитный сейсмический глубинный разрез через кольцевую структуру в надсолевых отложениях Прикаспийской впадины:

A - без корреляции, Б - с корреляцией горизонтов 


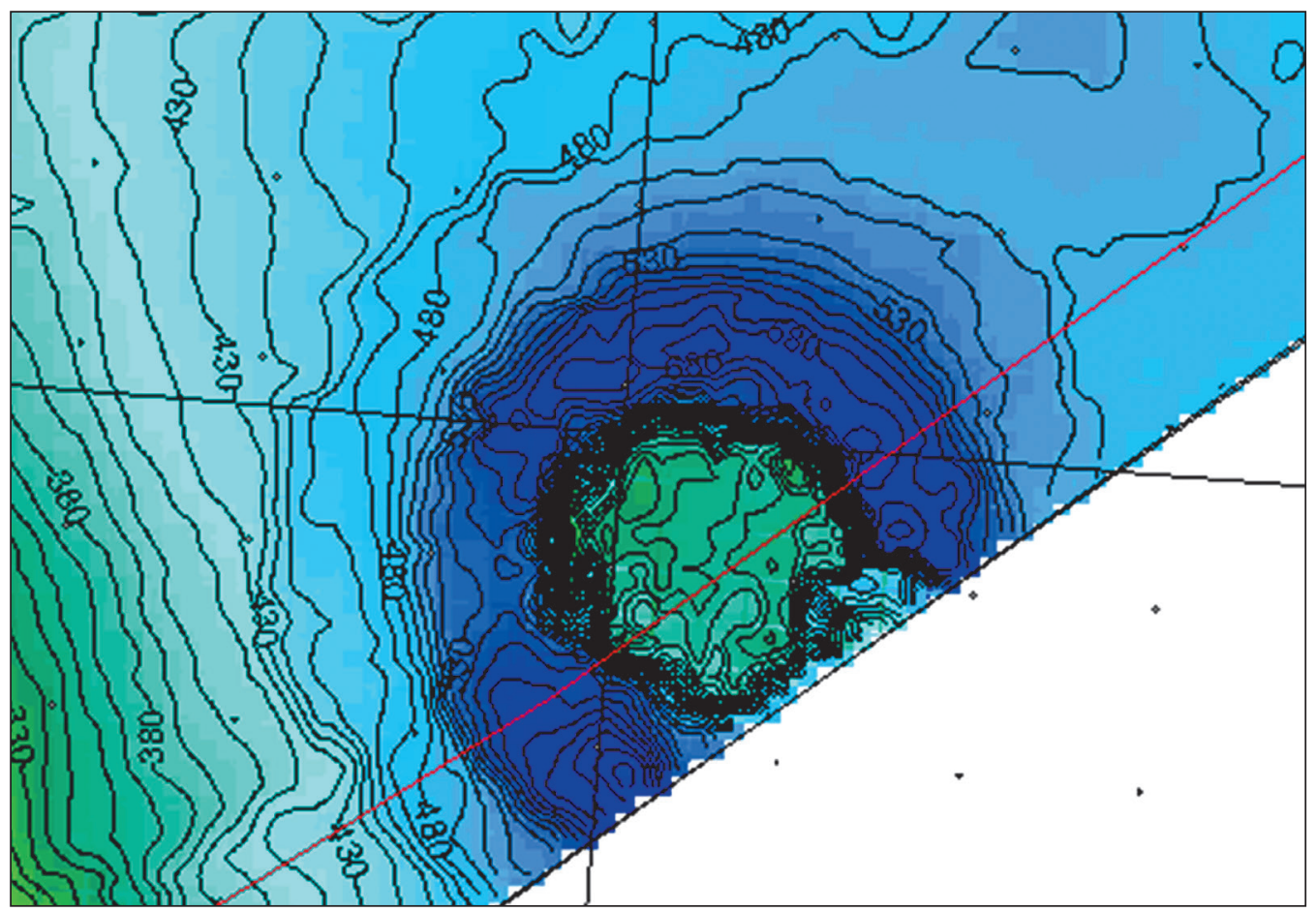

Рисунок 2 - Кольцевая структура. Карта изохрон горизонта III, подошва нижнемеловых отложений, красная линия - положение разреза на рисунке 1

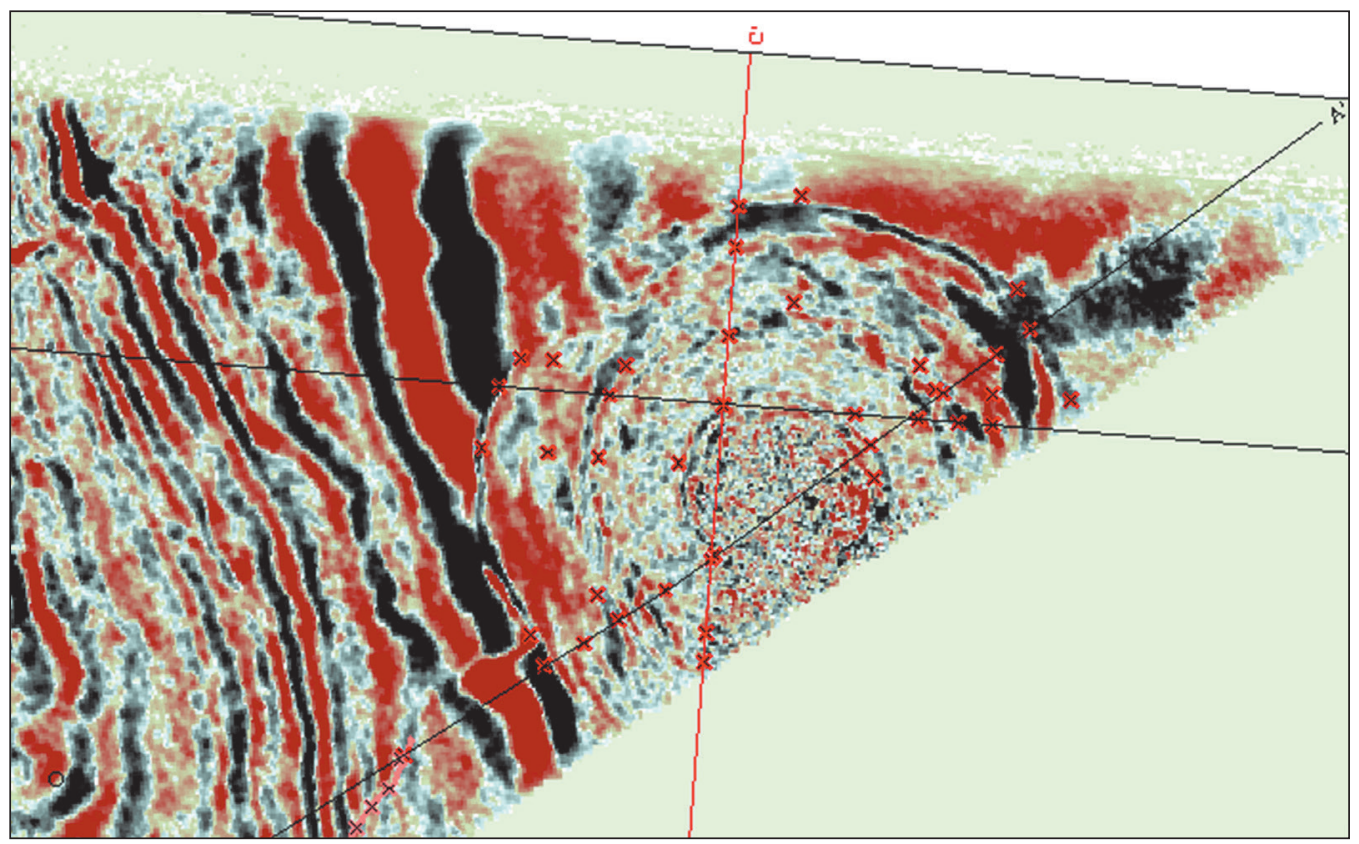

Рисунок 3 - Кольцевая структура. Амплитудный срез по уровню 430 мсек 


\section{ГЕОЛОГИЯ}

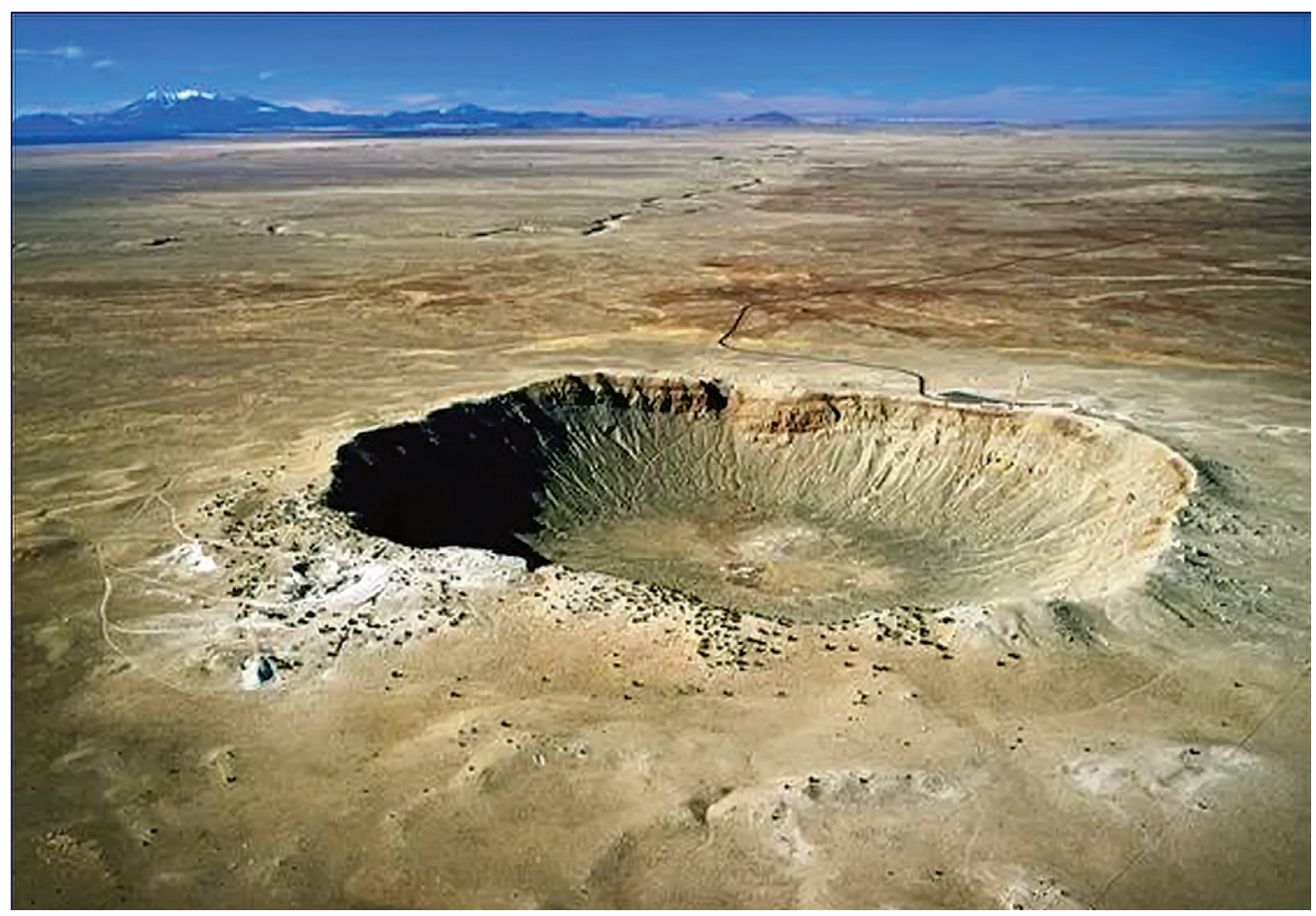

Рисунок 4 - Аризонский кратер (Кратер Барринджера) - один из крупнейших и лучше других сохранившийся метеоритный кратер, расположенный около каньона Дьябло на севере штата Аризона (США)

в три раза мощнее самого сильного взорванного ядерного заряда в истории - водородной «Царь-Бомбы». Есть, правда, оценки, что взрыв был только в 40 раз мощнее хиросимской бомбы. Считается, что метеорит содержал много никеля и железа, и поэтому относится к классу тяжелых метеоритов. Сила удара представляется опустошающей и сопровождалась землетрясением на месте падения силой, оцениваемой в семь баллов, которое ощущалось на большом расстоянии. Сам метеорит от силы удара частью испарился, частью его осколки разлетелись вокруг. Дождь из обломков метеорита и пород выпадал в радиусе в сотню километров.

Для того чтобы разобраться, чем кольцевая структура не похожа на метеоритный кратер, обратимся к рисунку 5, где представлена схема формирования ударных кратеров простого и сложного типов, почерпнутая из Интернета, и в которую полностью вписывается Аризонский кратер. Ударный кратер кольцевой метеоритной структуры должен быть сформирован за счетударного выброса породы по кольцу. На разрезах через кольцевую структуру (рисунок 1) такого не прослеживается. По кольцу прослеживается деформация пород - смятие для меловой части и уменьшение толщины для юрской. Если бы выявленная структура была следствием удара метеорита, то это произошло бы примерно в конце нижнего мела, которому соответствует горизонт II на рисунке 1. Над этим горизонтом по краям кольца был бы сформирован вал из выброшенных пород, высота которого составляла бы от четверти до половины глубины ударного кратера. На рисунке 6, где представлена карта 


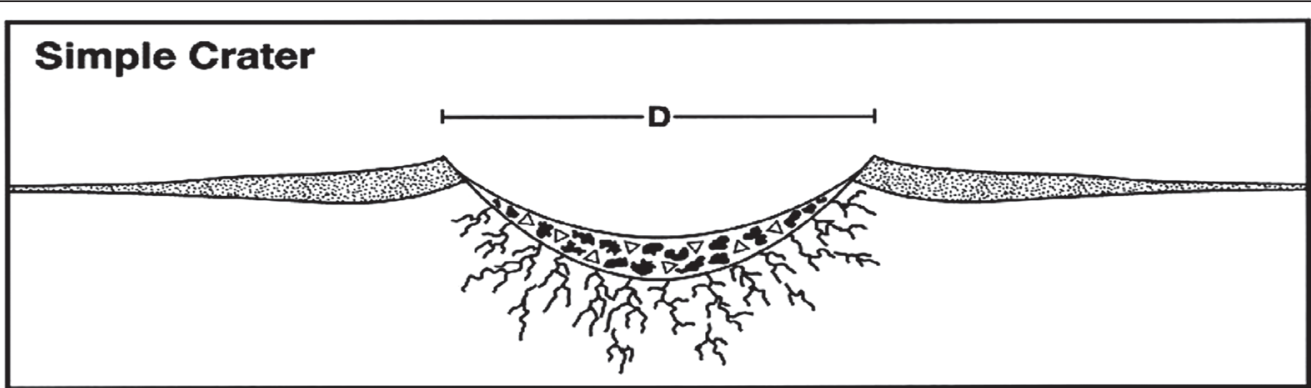

\section{$\triangle$ Breccia \\ - Impact melt \\ St. Fractured bedrock \\ Impact ejecta \\ $\int \|$ Central peak uplift}

\section{Complex Crater}

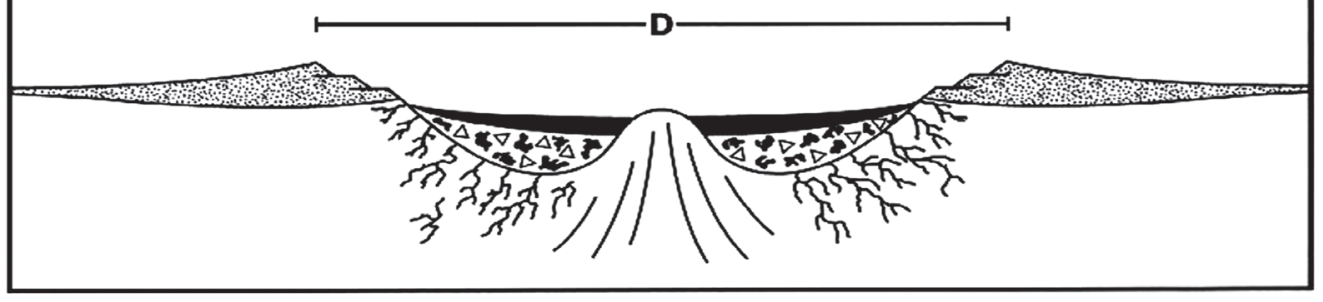

Рисунок 5 - Схема формирования простого, без центрального поднятия и сложного с центральным поднятием кратеров (из Интернета)

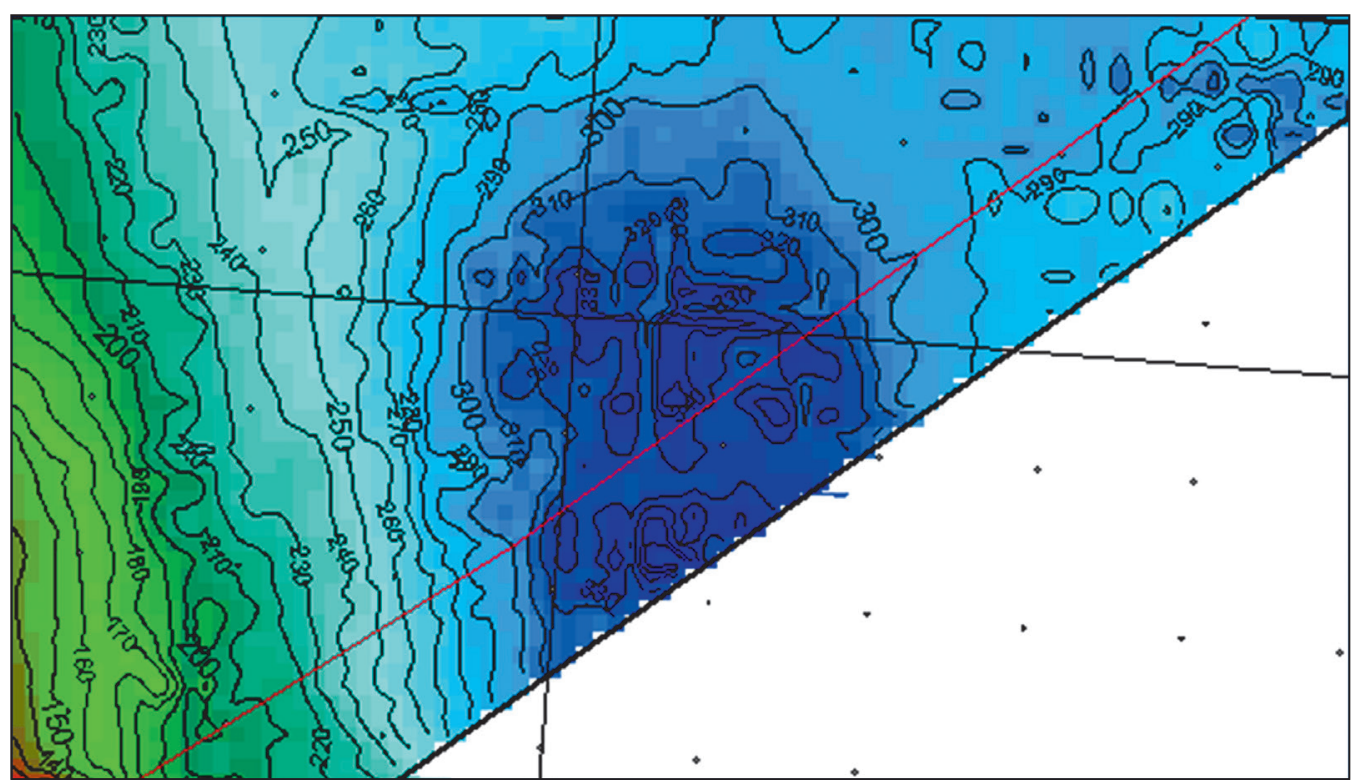

Рисунок 6 - Кольцевая структура. Карта изохрон нижнемелового горизонта (II), подошва верхнемеловых отложений. Красная линия - положение разреза на рисунке 1 
изохрон по горизонту II никакого валообразного поднятия вокруг края округлой структуры не прослеживается.

Другими словами, кольцевая структура выявлена в толще существенно ниже поверхности, на которую предполагаемый метеорит мог упасть, а на самой этой поверхности виден только чашеобразный, не очень глубокий (около 100 м) прогиб, который почти в два раза мельче Аризонского (184 м), при том, что диаметр последнего (1,2 км) в 4 раза меньше объекта (4,8 км). Судя по сейсмическим данным (рисунок 1), прогиб кольцевой структуры заполнен внизу брекчированной породой, а выше по всей площади он перекрывается отложениями с уровнем импеданса, таким же, как и для верхнеюрских карбонатных отложений (горизонт III). Эти отложения легко можно было бы принять за результат образования ударного расплава (impact melt), хотя в случае расплава импеданс мог бы быть значительно сильнее юрских карбонатов.

Собственно кратер вероятного удара метеорита представляется несопоставимым по размерам в сравнении с его последствиями в нижележащей толще (около 600 м), где нижнемеловые отложения (около 350 м) представлены перемятыми локальными кольцевыми вздутиями (меловой тороид), а юрские (в деформированной части около 250 м), наоборот сильно уплотненными в том же кольце, с деформациями смещения по тектоническим нарушениям. Юрские отложения оказались уплотненными в такой мере, в какой нижнемеловые формируют раздув толщины в кольце, в сумме толщины остаются практически постоянными. В незатронутой части разреза соотношение толщин обратное - 400 м толщина юрской части и 200 м толщина нижнемеловой. Особенно хорошо это видно на разрезах по инлайну и крослайну (рисунок 7), где особенности строения кольцевой структуры проявляются еще более четко, чем на композитном разрезе.

Если выявленная кольцевая структура по своим параметрам не очень подходит под ударный метеоритный кратер, то чем же на самом деле она является? Подобная структура могла бы быть сформированной солянокупольной тектоникой. Конечно, в данном случае это будет не та обычная солянокупольная тектоника, заключающаяся в медленном конседиментационном подъеме соли, в результате которой в основном формировались соляные купола впадины. В данном случае это будет своего рода внедрение, соляной шток, который внедрился в перекрывающие отложения, приобретя наиболее энергетически выгодную, круглую форму. Как это может выглядеть на сейсмическом разрезе, показано на рисунке 8 , где дана корреляция для солянокупольного варианта образования кольцевой структуры. Очевидно, что мощный импульс соляная масс получила на глубине, а способность к перемещению, возможно, связана с положением этой соли на границе купол-мульда, где в этом процессе могли принимать участие УВ, способствуя снижению вязкости вещества. Только формирование в течение длительного времени привело к тому, что последствия формирования структуры по солянокупольному сценарию были не такими разрушительными для окружающей среды, как метеоритный удар.

Нужно отметить, что солянокупольные структуры круглой формы в Прикаспии известны давно. По сейсмическим данным купола круглой формы, обычно имеющие относительно небольшую площадь, прорывают вмещающие отложения, которые к стенкам купола примыкают по нормали. Какого-то влияния такие купола на окружающее поле солянокупольных структур, как правило, не оказывают и, очевидно, 


\section{ГЕОЛОГИЯ}

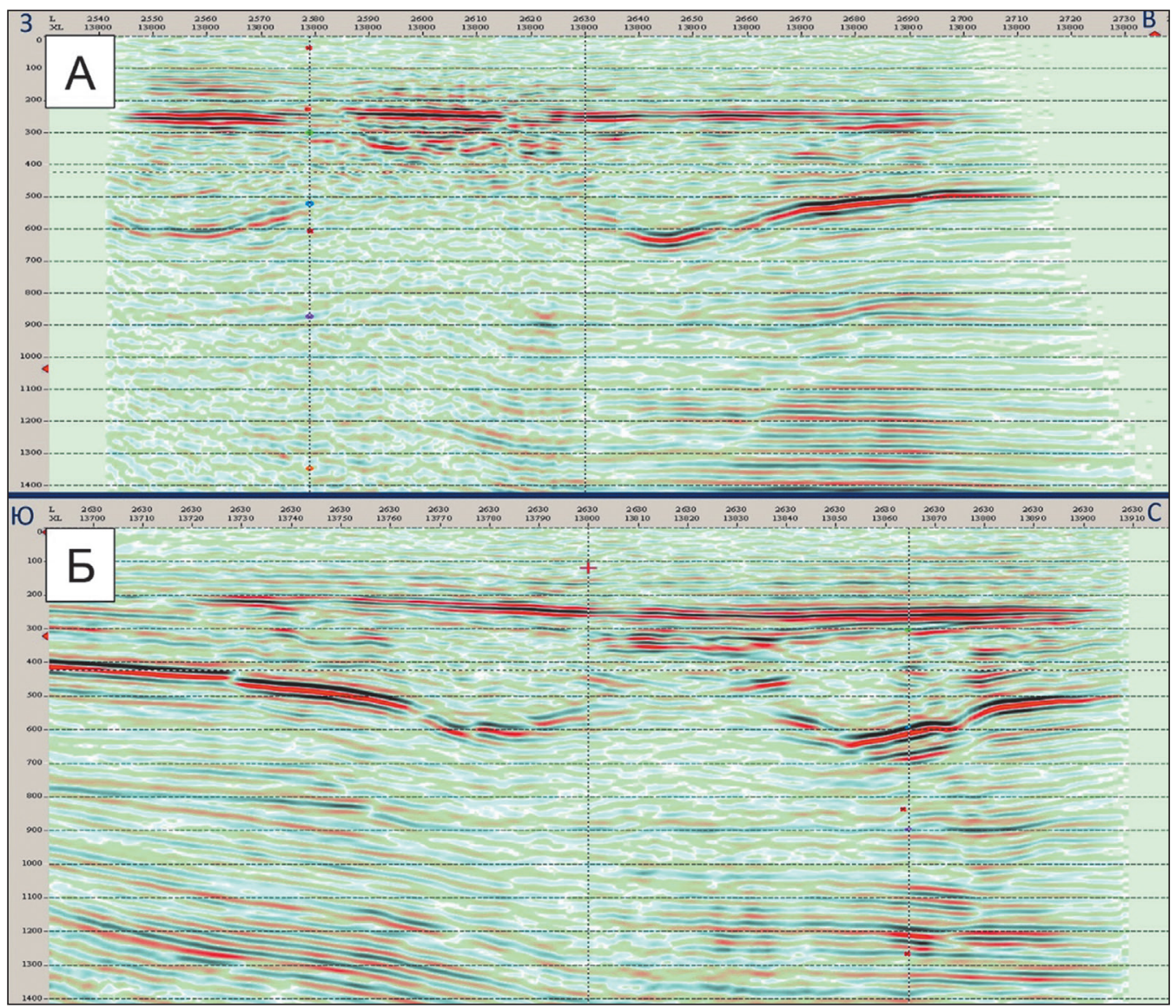

Рисунок 7 - Глубинные сейсмические разрезы кросслайн (А) и инлайн (Б), пересекающие кольцевую структуру. Пересечение разрезов показано пунктирными вертикальными линиями, а их положение дано на рисунках 1, 3 и 5

что они имеют по отношению к этому полювторичный характер, сформировавшись на поздних этапах галокинеза.

Таким образом, выявление специфичной меловой кольцевой структуры еще раз показывает, что далеко не всё в формировании солянокупольных структур изучено, a, значит, можно полагать, что многие вопросы строения и формирования соляных куполов, а с ними и ловушек УВ в надсолевом комплексе вместе с путями миграции из подсолевых отложений еще ожидают своего решения. Вполне очевидно, что всевозрастающие объемы сейсморазведки МОГТ 3Д, проведенные в Прикаспийской впадине, открывают новые возможности для изучения как особенностей строения, особенно на глубинах больше 2-3 км, так и формирования солянокупольных структур, а вместе с этим и распределения коллекторов, ловушек и путей миграции к ним УВ.

Было бы совершенно непростительным, если бы эти возможности остались не использованными в самой краткосрочной перспективе. И здесь роль различных институтов республики, включая и Академию наук, как никогда велика. Вполне напрашивается бурение нескольких скважин глубиной 500-600 м на кольцевой 


\section{ГЕОЛОГИЯ}

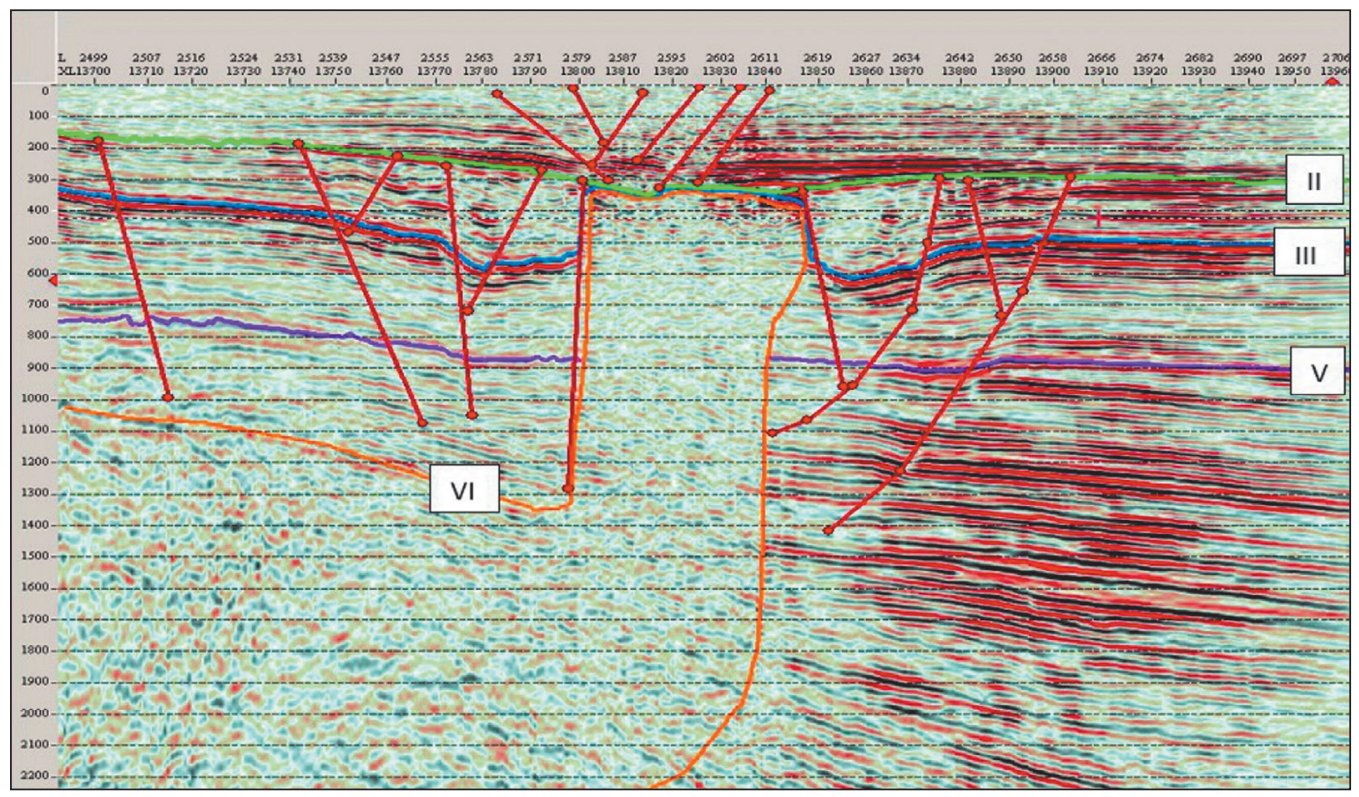

Рисунок 8 - Вариант интерпретации кольцевой структуры, возникшей благодаря солянокупольной тектонике (см. рисунок 1Б)

структуре для построения надежной модели ее формирования как естественного звена в цепочке изучения куполов и их нефтегазоносности. Но будет ли это сделано в интересах лучшего понимания строения и развития основной нефтегазоносной провинции республики, в сегодняшних условиях - большой вопрос.

\section{ЛИТЕРАТУРА}

1 Волож Ю.А., Трохименко М.С., Калимов А.М., Едилбаев М.Т. Каспийский регион: кольцевые субвертикальные структуры, покмарки и экс-покмарки. Часть I // Нефть и Газ. - 2019. - № 6 (114). - C. 15-50. [Volozh Yu.A., Trokhimenko M.S., Kalimov A.M.,Yedilbayev M.T. The Caspian Basin: annular sub-vertical structures, pockmarks and expockmarks. Part I // Neft' i Gaz. - 2019. - № 6 (114). - P. 15-50.]

2 Волож Ю.А., Трохименко М.С., Калимов А.М., Едилбаев М.Т. Каспийский регион: кольцевые субвертикальные структуры, покмарки и экс-покмарки. Часть II // Нефть и Газ. - 2020. - № 2 (116). - C. 11-37. [VolozhYu.A., Trokhimenko M.S., Kalimov A.M., Yedilbayev M.T. The Caspian Basin: annular sub-vertical structures, pockmarks and expockmarks. Part II // Neft' i Gaz. - 2020. - № 2 (116). - P. 11-37.]

3 Зейлик Б.С., Надиров Н.К., Кадыров Д.Р. Новая методика прогнозирования нефти и газа. // Нефть и газ. - 2010. - №5. - C. 105-120. [Zeylik B.S., Nadirov N.K., Kadyrov D.R. A new methodology for predicting oil and gas. // Neft' i gaz. - 2010. -№5. - P. 105-120.]

4 Надиров Н.К. Краткие комментарии к научно-теоретическим исследованиям Б.С. Зейлика по разработке инновационной методики поисков месторождений углеводородов на базе дистанционного зондирования Земли (ДЗ3) и ударно-взрывной тектоники (УВТ). // Известия НАНРК. Сер. геол. и тех. наук. - 2014. - №1(403). - С. 83-88. [Nadirov N.K. Brief Comments to B.Z. Zeilik's Scientific and Theoretical Research on the Development of Innovative Methods for Prospecting Hydrocarbon Fields on the Basis of Remote Sensing of the Earth (RS) and Shock Explosion Tectonics (SET). // Izvestiya NAN RK, seriya geologii I tekhnicheskikh nauk. - 2014. - №1(403). - P. 83-88.] 